\title{
The Near-Surface Small-Scale Spatial and Temporal Variability of Sensible and Latent Heat Exchange in the Svalbard Region: A Case Study
}

\author{
Georg Jocher, ${ }^{1}$ Florian Karner, ${ }^{2}$ Christoph Ritter, ${ }^{1}$ Roland Neuber, ${ }^{1}$ \\ Klaus Dethloff, ${ }^{1}$ Friedrich Obleitner, ${ }^{2}$ Joachim Reuder, ${ }^{3}$ and Thomas Foken ${ }^{4}$ \\ ${ }^{1}$ Alfred Wegener Institute for Polar and Marine Research, Telegrafenberg A43, 14473 Potsdam, Germany \\ ${ }^{2}$ Institute of Meteorology and Geophysics, Innsbruck University, Innrain 52, A-6020 Innsbruck, Austria \\ ${ }^{3}$ University of Bergen, Allegaten 70, N-5007 Bergen, Germany \\ ${ }^{4}$ University of Bayreuth, Universitätsstrasse 30, 95447 Bayreuth, Germany
}

Correspondence should be addressed to Georg Jocher, georg.jocher@awi.de

Received 11 May 2012; Accepted 10 June 2012

Academic Editors: D. Bourras and A. Saha

Copyright ( $) 2012$ Georg Jocher et al. This is an open access article distributed under the Creative Commons Attribution License, which permits unrestricted use, distribution, and reproduction in any medium, provided the original work is properly cited.

\begin{abstract}
We present data from two eddy covariance systems for determining the sensible and latent heat flux and the shear stress near the earth's surface. One measures continuously since September 2010 close to the village Ny-Ålesund, Svalbard, the other one was located on Kongsvegen glacier for a short period in April 2011. Two examples for small-scale variability are discussed: near surface external gravity waves associated with katabatic wind from the Broggerbreen glacier located a few kilometres southwestern of Ny-Ålesund, and an episode when the two eddy systems at the different measurement sites captured very different conditions at the same time. In case of gravity wave motion the eddy covariance method results in fictitious positive fluxes due to the strong correlation between temperature and vertical wind, which has to be considered carefully. The comparison between the two sites showed that generally the dynamical processes near the Earth's surface for Ny-Ålesund and the Kongsvegen glacier are different and local. But there are also cases of synchronization due to synoptic influences, and then the same processes are visible at the two measurement sites. Both examples show that the boundary layer in Ny-Ålesund is not only affected by the main glaciers in the east of the village, but also by other orographical characteristics and synoptic issues. Therefore, the only meaningful way to deal with point measurements is to consider them in context with the surrounding orography and the general meteorological conditions.
\end{abstract}

\section{Introduction}

Dynamical processes near the Earth's surface are important and affect the whole atmospheric boundary layer. In Arctic environments, near-surface temperature inversions are prominent phenomena which essentially influence surface energy exchanges during stable stratification and drive important local and regional atmospheric circulations. A proper treatment of such phenomena in atmospheric models is still a problem, which in part is due to improper horizontal resolution (about 25-50 km). On the other hand, existing subgrid-scale parameterizations have still problems to describe these processes in a correct way [1]. Further, there is also a need of relevant data for input and validation of model results, which are still sparse in Arctic environments particularly. So, it is essential to get more data of the near surface processes to complement and amplify the existing work on this field at Svalbard (e.g., [2] or [3]). This is of most importance for a better understanding of the underlying physics, for the appreciation of the interaction of these processes with the whole Arctic atmospheric boundary layer, and finally, to take account of these processes in numerical weather prediction and climate models as much as possible. Another approach to solve the problem of the linkage between small-scale and large-scale processes is, for example, the Large-Eddy simulation [4].

Boundary layer measurements started in Ny-Ålesund several years ago. Beine et al. [7] analysed the wind profile 


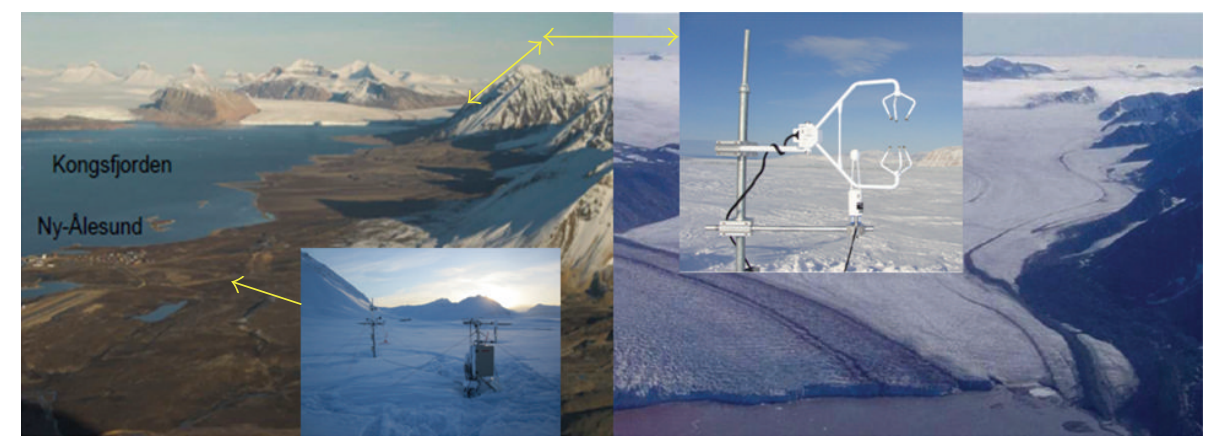

(a)

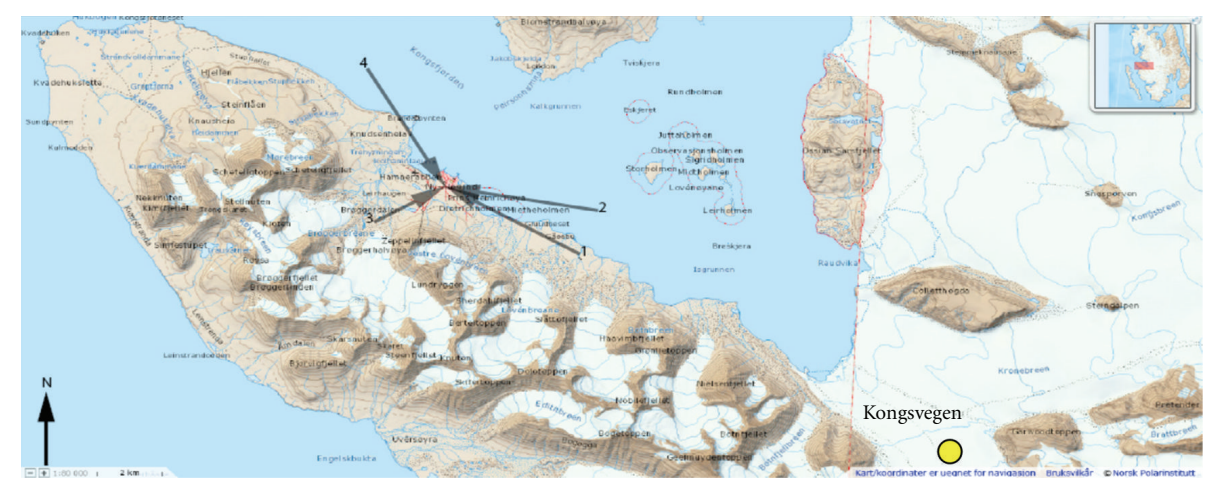

(b)

Figure 1: The Kongsfjord region on Svalbard (upper left side), including both measurement sites Ny-Ålesund and Kongsvegen glacier (marked with arrows). The overview picture is taken from [5]. The upper right picture [6] shows the Kongsvegen measurement site. Beneath a topographical map of the Kongsfjord region (http://www.toposvalbard.npolar.no/) is shown. The arrows in the map mark the dominant wind directions in Ny-Ålesund, most often are 1 and 2 (eastern directions). 3 marks the direction downward the Broggerbreen glacier, 4 the free ocean, and the yellow dot the eddy covariance system on the Kongsvegen glacier.

and found prevailing winds from south-east which were interpreted as katabatic outflows from the glaciers to the east, namely, the Kongsvegen and the Kronebreen glacier. Argentini et al. [8] presented data on wind and thermal structure of the boundary layer and found stably stratified conditions with gravity waves excited at low wind speeds. Forced convection due to mechanical turbulence was found at higher wind speeds. Recently, Vihma et al. [9] investigated air temperature and humidity inversions and low-level jets over two Svalbard fjords, one was the Kongsfjorden, where Ny-Ålesund is located. These examples and also the recent construction of the $32 \mathrm{~m}$ high Italian Amundsen Nobile Climate Change tower [10] near Ny-Ålesund demonstrate the significance of boundary layer measurements to understand the processes in the whole atmosphere as much as possible.

The mentioned investigations already showed a high temporal and spatial variability of the near-surface exchange processes. The reason for this high variability can probably be found in the complex orography around the site, including the coast. Thus, Ny-Ålesund is indirectly influenced by the Gulf Stream and resembles more tundra climate, hence, results concerning the boundary layer processes derived at that place cannot be simply generalized for the Arctic as a whole. Therefore, the site of Ny-Ålesund is in actual fact not well suited for Arctic boundary layer measurements, in spite of its easy accessibility, the disparities in space and time are too pronounced. A more detailed understanding on how the synoptic meteorological situation interacts with orography and small-scale processes is, therefore, urgently needed.

In this work data from two eddy covariance stations, one close to the village and a second on Kongsvegen glacier are analysed. A case of gravity wave motion at the measurement site near $\mathrm{Ny}$-Ålesund, triggered by katabatic outflows of the Broggerbreen glacier and the orography was captured as an example for the high temporal near-surface process variability. Moreover, cases of similar and different conditions in comparison of both measurement sites will be discussed to analyse the small-scale spatial variability in this region.

The presented periods (November 2010 for discussing the temporal variability, April 2011 for the spatial variability) were chosen due to their representativeness of the mentioned issues.

\section{Sites and Methods}

2.1. Eddy Covariance System Ny-Ålesund. Ny-Ålesund on Svalbard (Figure 1) is a centre for different polar research institutions, also for the Alfred Wegener Institute AWI (AWIPEV research station). The eddy covariance system 
$\left(\mathrm{N} 78^{\circ} 55.287^{\prime}, \mathrm{E} 011^{\circ} 54.851^{\prime}\right)$ is located about $300 \mathrm{~m}$ south of the meteorological observatory of Ny-Ålesund about halfway between the observatory and the Zeppelin mountain on the rather flat bare tundra. The position has mainly been chosen because of the quite homogeneous footprint area around.

The snow height during the relevant periods was $0.4 \mathrm{~m}$ in April 2011 (effective measurement height $1.7 \mathrm{~m}$ ) and $0.05 \mathrm{~m}$ in November 2010 (effective measurement height $2.05 \mathrm{~m}$ ).

2.2. Eddy Covariance System Kongsvegen Glacier. The distance between the eddy covariance complex near Ny-Ålesund and the measurement system on the Kongsvegen glacier is about $15 \mathrm{~km}$. Kongsvegen is one of the few Svalbard glaciers where long-term meteorological and mass balance measurements are performed. The glacier drains into Kongsfjorden and originates at a saddle connecting to the south flowing Sveabreen ( $800 \mathrm{~m}$ a.s.l.). It covers an area of $101 \mathrm{~km}^{2}$, and has a length of $26 \mathrm{~km}$, slopes are gentle and have a north-westerly aspect. The turbulence measurements were performed at the tongue of the glacier at an elevation of $162 \mathrm{~m}$ a.s.l. ( $\mathrm{N} 78^{\circ} 50.725^{\prime}$, E $\left.012^{\circ} 40.106^{\prime}\right)$. The local slope of the surface is oriented towards NW, that is, towards the Kongsfjorden coast. The surface conditions at this site are characterized by snow during winter and bare ice during summer. Transitions, the changes from snow to ice and vice versa, usually occur in May and September. At the time of the turbulence measurements considered here (April 2011), the surface was still covered by snow. The measured snow depth was $67 \mathrm{~cm}$ (referring to the underlying glacier ice) and the average density of the snow pack was $331 \mathrm{~kg} \mathrm{~m}^{-3}$. The surface roughness may be characterized as slightly undulating sastrugi structures upon which small ripples were present.

So far, micrometeorological or turbulence measurements have not been performed at Kongsvegen glacier except of a study performed about $150 \mathrm{~m}$ higher up at the glacier during summer 2008 [6]. These data revealed temperature inversions in excess of $10^{\circ} \mathrm{C}$ within the lowest $15 \mathrm{~m}$ above the surface and a katabatic wind maximum occurring frequently $5-10 \mathrm{~m}$ above the surface. The katabatic wind speeds, therefore, reached a maximum velocity of $4 \mathrm{~ms}^{-1}$, the absolute wind maximum downward the glacier as combination of katabatic and synoptic forcing went up to $15 \mathrm{~ms}^{-1}$. Turbulence characteristics were not yet evaluated.

Turbulence measurements cannot routinely be performed at the glacier due to problems concerning for example appropriate power supply, proper alignment of instruments at the moving glacier surface, accretion of snow, and rime or data retrieval. The data considered in this study are based on measurements during the period from 6 April to 1 May 2011, contemporary to the Pan-Arctic Measurements and Arctic Regional Climate Model Simulation Project (PAMARCMiP) 2011, when the station was visited at least twice a week for proper maintenance. The equipment was mounted at a tripod which was frozen into the ice and stabilized by guy wires. To minimize disturbances by the mast and supports, the sensors were mounted towards north-east that is, perpendicular with respect to the prevailing wind direction (down slope).

2.3. Instrumentation and Data Processing. The measurements employ a sonic anemometer CSAT 3 for determining the high-frequency fluctuations of the wind components and the temperature and an LiCor 7500 for the humidity fluctuations for both stations. All the values were sampled with $20 \mathrm{~Hz}$ frequency. The sensors were mounted at a height of $2.1 \mathrm{~m}$ above ground, the data postprocessing was made with the internationally compared eddy covariance software TK 3 $[11,12]$. This software includes the option to use spike detection, the conversion from the buoyancy flux to the "real" sensible heat flux and the rotation of the measured data in the actual streaming field (double rotation was used here) which was applied for all calculations in this context.

Most important for a meaningful use of the eddy covariance method [13] is the exact application of all corrections and quality tests according to Foken et al. [14] and Foken et al. [15]. The eddy covariance method needs horizontally homogeneous surfaces, steady-state conditions, and ideally well-developed turbulence. Obviously these mentioned requirements pose severe limitations especially in Arctic regions frequently. Svalbard is not horizontally homogeneous, well-developed turbulence is quite rare in the Arctic and steady-state conditions not the normal case. This has to be considered carefully in the data handling, in Lüers and Bareiss [2], for example, are some issues of that problem discussed.

As background, the following quantities were collected with a lower frequency $(1 \mathrm{~Hz}$, second mast) at the $\mathrm{Ny}$ Ålesund site: wind velocity, wind direction, temperature, air pressure, absolute and relative humidity all at $2 \mathrm{~m}$ height, as well as the surface temperature and snow height during winter. Further, there is an additional temperature profile measurement on this mast ( 3 instruments at 1.5, 1, and $0.5 \mathrm{~m}$ height) and a small soil profile next to the mast with measurements of temperature in 1 and $10 \mathrm{~cm}$ soil depth, a heat flux plate in $10 \mathrm{~cm}$ depth and a TDR (Time Domain Reflection) instrument for measuring the soil humidity.

\subsection{The Meteorological Background}

2.4.1. General Meteorological Conditions at the Two Measurements Sites. Standard meteorological measurements were performed using automatic weather stations at the two turbulence measurement sites including, for example, the radiation components and surface height changes. These data allow the documentation of the general conditions during the investigation period. Further, these studies are valuable with respect to the interpretation and spatial representativeness of the turbulence data.

Considering mean annual values (May 2010 to April 2011), air temperature is about 2 degrees lower at the Kongsvegen site in comparison with $\mathrm{Ny}$-Ålesund (-4.3 versus $-6.4^{\circ} \mathrm{C}$ ). This reflects the different elevation as well as different surface conditions. The latter mainly evolves during summer, when there is permanent snow and ice at the glacier, 
while bare tundra is present at Ny-Ålesund. Mean annual albedo is correspondingly higher at the glacier in the annual mean ( 0.3 versus 0.6$)$. The atmospheric boundary layer at the glacier is characterized by lower humidity and higher wind speeds than the site $\mathrm{Ny}$-Ålesund.

Figure 2(b) shows the typical frequency distribution of wind directions observed at the glacier from May 2010 to April 2011. The pattern is characterized by frequent and strong south-easterly winds. Their nature is primarily associated to topographically modified synoptic winds and katabatic forcing. The SE-NW alignment of the surrounding mountain ranges and the presence of Kongsvegpasset play a major role in this context. The secondary peak from northwesterly directions is associated to cold air advection in the rear of low-pressure systems passing the area.

Modelling studies by, for example, Skeie and Gronas [16] or Sandvik and Furevik [17] suggest that glacier winds also influence the wind conditions at $\mathrm{Ny}$-Ålesund located about $15 \mathrm{~km}$ downstream of Kongsvegen glacier. This is corroborated by our observational data (Figure 2(a)) which reflect the general orientation of Kongsfjorden orography and the prevalence of winds from the glacierized areas to the southeast. Beine et al. [7] also stated that the predominant flow at $\mathrm{Ny}$-Ålesund is from the east-southeast due to katabatic flow from the Kongsvegen glacier around $15 \mathrm{~km}$ to the east of Ny-Ålesund. But this is not always valid, as will be shown later in Section 3. The comparatively frequent winds from south-west are explained as downslope katabatic winds draining along the slopes of Zeppelin mountain range south of $\mathrm{Ny}$-Ålesund. Svendsen et al. [18], Argentini et al. [19] and Hartmann et al. [20] showed that the occurrence of these winds is strongly related to the position of the low pressure systems in the area.

2.4.2. Selection of the Periods for the Case Studies. From 25 March to 6 May 2011, the international PAMARCMiP (Polar Airborne Measurements and Arctic Regional Climate Model Simulation Project) 2011 took place. This campaign aimed to measure sea ice thickness and extent next to various key meteorological quantities, including aerosol from a Basler BT 67 aircraft. From 30 April to 5 May, the plane operated from Longyearbyen. Two overflights over Ny-Ålesund could be realised for aerosol, radiation, and boundary layer measurements. The turbulence measurements at Kongsvegen glacier were performed to further support these activities focusing on glacier environments, which are prominent in the Kongsfjord area and Svalbard. Moreover, these data may be used for validation of energy balance calculations at the glacier based on standard parameterizations, and to investigate the glacier's atmospheric boundary layer and the skill of numerical weather prediction and regional climate model output, respectively.

The preliminary analysis of the available turbulence dataset revealed 2 interesting typical features, representing the temporal and spatial variability of micrometeorological processes in this region, which will be investigated in detail in this study. The evaluated data stem from two periods, that is, 6 November 2010 to 9 November 2010 and 8 April 2011 to
9 April 2011. The former addresses gravity wave phenomena observed at Ny-Ålesund and related methodical issues. The latter focuses on the spatial variability of the exchange characteristics comparing contemporary data collected at $\mathrm{Ny}-\AA ̊ \AA l$ lesund and Kongsvegen. The two periods were chosen due to their representativeness of the mentioned issues.

\subsubsection{Meteorological Background of the Investigated Days in November 2010}

(a) 6 November 2010 and 7 November 2010. Figure 3 shows a summary of relevant variables in the course of the investigated days. On the left panel, a period with gravity waves is depicted, clearly to see are the inversion and the quite small wind velocities coming from about $210^{\circ}$.

The radiation budget is negative because of the longwave radiation loss at the surface. For the investigated period with gravity waves, the Brunt-Vaisala frequency is quite high (shown later). This reflects the extreme difference between the surface temperature and the temperature at the measurement height caused by radiative cooling at this time. $z / L$ is negative because of the fictitious positive sensible heat flux, which was measured due to the existence of the gravity waves.

(b) 8 November 2010 and 9 November 2010. On the right panel of Figure 3, a period without gravity waves is shown, the inversion is almost gone, the wind speed is larger, and the wind direction is different. The radiation budget is nearly around zero because of clouds (less longwave radiation loss), the stability parameter is zero or positive.

\subsubsection{Meteorological Background of the Investigated Days in} April 2011

(a) 8 April 2011. On this day it was quite cold (between -13 and $-7^{\circ} \mathrm{C}$ ) and dry, the sun was shining and the atmosphere was clear. The wind speed was always lower than $5 \mathrm{~ms}^{-1}$, the direction was oscillating around south. In the evening clouds began to appear. To visualize this, Figure 4 with the wind speed and wind direction is added, produced with data from the BSRN weather mast, a $10 \mathrm{~m}$ height mast with different meteorological instruments. Used were the data from the 2 and $10 \mathrm{~m}$ wind velocity and direction measurement.

Because of its height, this mast has a larger footprint area, and is, therefore, ideal for reference measurements. Furthermore, it is located nearby Ny-Ålesund, about $200 \mathrm{~m}$ in the east of the formerly introduced eddy covariance system.

(b) 9 April 2011. It was a little bit warmer (between -6 and $-3^{\circ} \mathrm{C}$ ) with more humidity on this day in comparison to the 8 April 2011. The whole day there was a cloud cover, the wind velocity was still quite low, the wind direction was oscillating. Quite suddenly at about 17 UTC the wind freshed up, the wind direction changed to west-northwest and the temperature went down to about $-10^{\circ} \mathrm{C}$ quite quickly (Figure 5). 


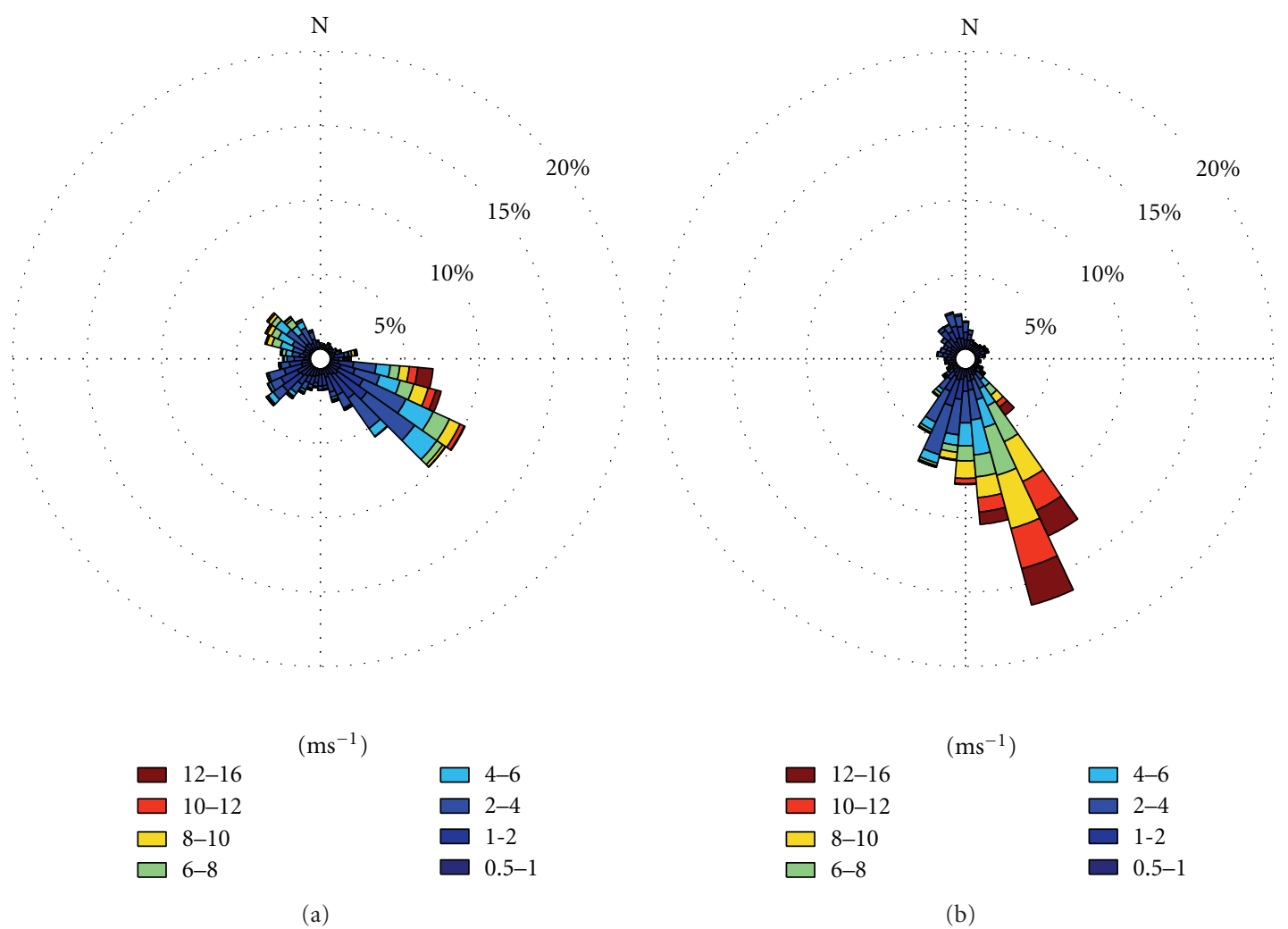

Figure 2: Average wind direction frequency distribution at the Ny-Ålesund (a) and Kongsvegen measurement site (b) from May 2010 until April 2011.

As an overview, diverse meteorological values for both measurement sites and both days are summarized in Figure 6. In the left panel are the values shown for the NyAlesund site, in the right panel are the values shown for the Kongsvegen site. $z / L$ is fluctuating at the Ny-Ålesund site because of the small sensible heat flux. Is the sensible heat flux fluctuating around zero, the Obukhov length is also fluctuating between positive and negative values, and thereby $z / L$. Detailed analyses are following in Section 3.

\section{Results and Discussion}

3.1. Temporal Variability of Sensible and Latent Heat Exchange in Arctic Regions: Near-Surface Gravity Waves. The occurrence of a shallow inversion layer above the surface, snow, or ice in Polar Regions in about 1 to $2 \mathrm{~m}$ height is nowadays known (e.g., [21]), a disturbed temperature profile in the lowest meters of the atmosphere can be caused by strong cooling and by strong heating at the mentioned interface .

In both cases of a narrow inversion the layers below and above the change of temperature gradient are mostly decoupled, a problem for the measurement of heat fluxes, because the determined fluxes do not represent the heat fluxes at the surface (Lüers and Bareiss 2010 [22]). For exact conclusions about the vertical energy transfer, the different layers have to be observed separately.
If the inversion is caused by radiative cooling (for external gravity waves, the density of the lower layer has to be larger than the density of the layer above the change of temperature gradient), at the interface between the layers below and above the inversion, external gravity waves can develop [23]. External gravity waves are oscillating vertically and propagating horizontally. The range of gravity wave motions is given by the Brunt-Vaisala frequency, which describes the maximum oscillation frequency of a vertically displaced mass element in the vertical column [24].

Figure 7 shows the potential temperatures at the surface and the measurement height (a) and the Brunt-Vaisala frequencies (b) for the period 6 November 201000 UTC to 7 November 201024 UTC on the left side, a period with gravity wave developing. As contrast on the right side in the same graphic, the period 8 November 201000 UTC to 9 November 201024 UTC is plotted, a period mostly without gravity wave developing. Only a short distance in this period shows the preconditions for gravity waves.

The discrepancy in the temperature and frequency behaviour is obvious. Per definition gravity waves should be seen in the air pressure developing, the wavelet plot Figure 8(a), for which the Mexican hat wavelet was used, approves this clearly for our measurement period. For example, the air pressure at the measurement height for a period from 6 November 2010 (08 to 16 UTC) is pictured, a period where gravity waves were found. The powerful processes in the frequency range of the gravity waves (at 

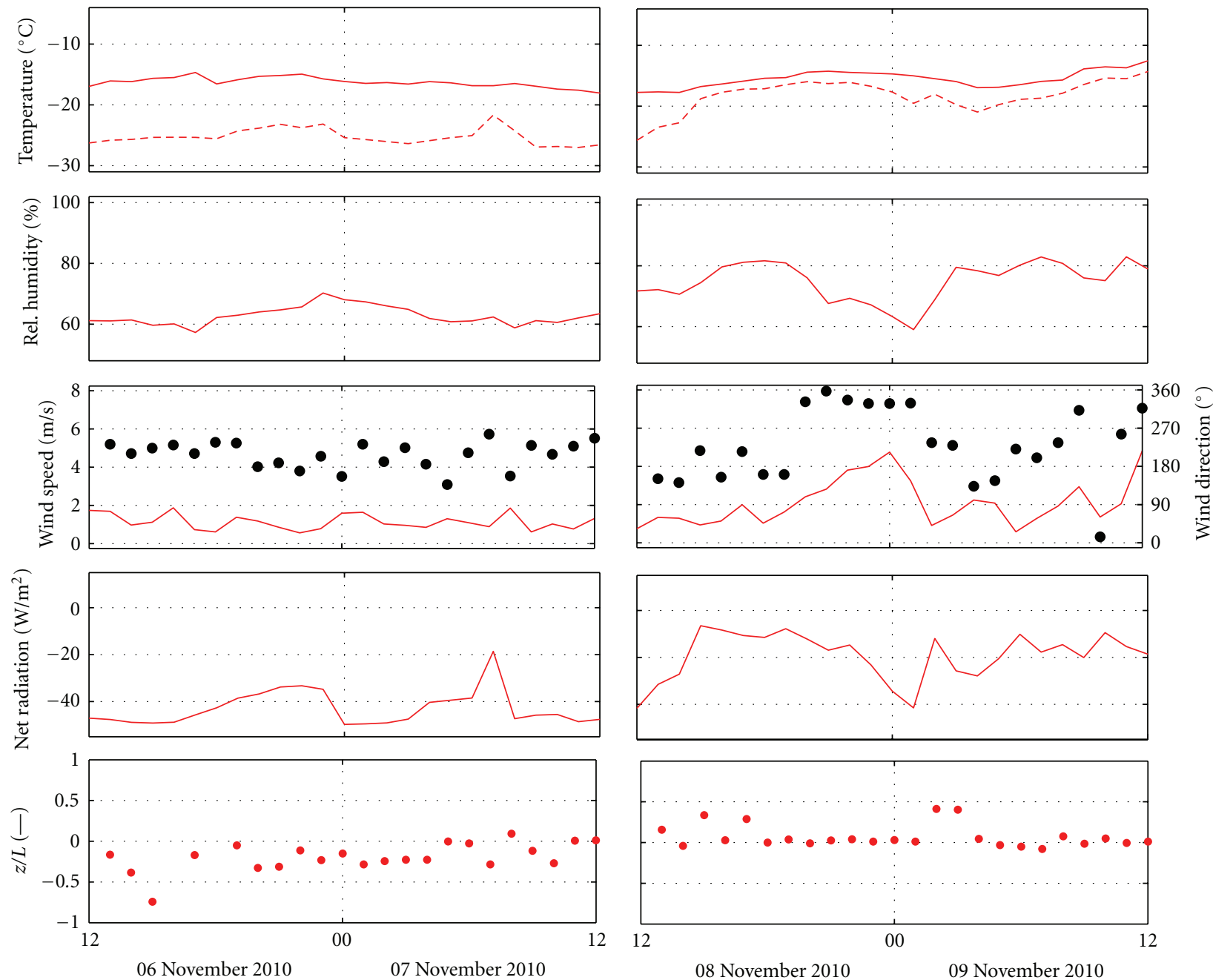

08 November 2010

09 November 2010

$\begin{array}{ll}- & \text { Air }(2 \mathrm{~m}) \\ -- & \text { Surface }\end{array}$

- Air $(2 \mathrm{~m})$

- - Surface

(a)

(b)

Figure 3: Temperature at $2 \mathrm{~m}$ and at the surface, humidity, wind velocity (line) and wind direction (dots), radiation budget and the stability parameter $z / L$ for the time period 6 November 2010-9 November 2010 (from the top to the bottom).

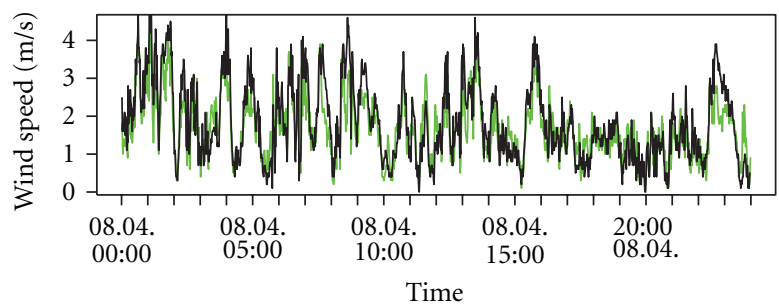

(a)

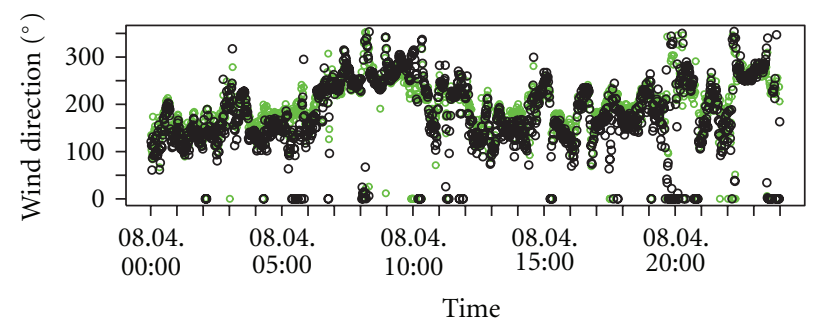

(b)

FIGURE 4: Wind speed and wind direction for 8 April 2011 at the BSRN weather mast, plotted are the values for 2 (green) and 10 (black) m height. 


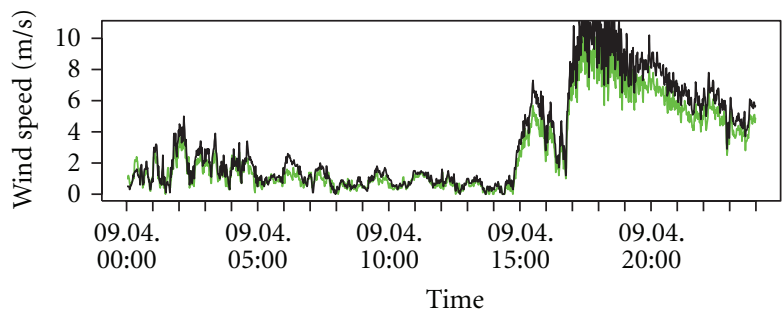

(a)

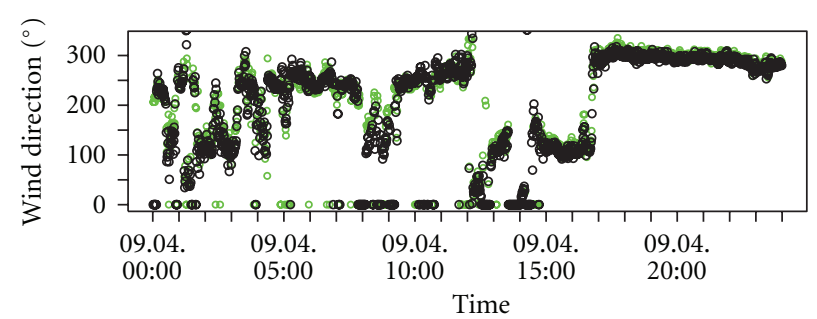

(b)

FIGURE 5: Wind speed and wind direction for 9 April 2011 at the BSRN weather mast, plotted are the values for 2 (green) and 10 (black) $\mathrm{m}$ height.
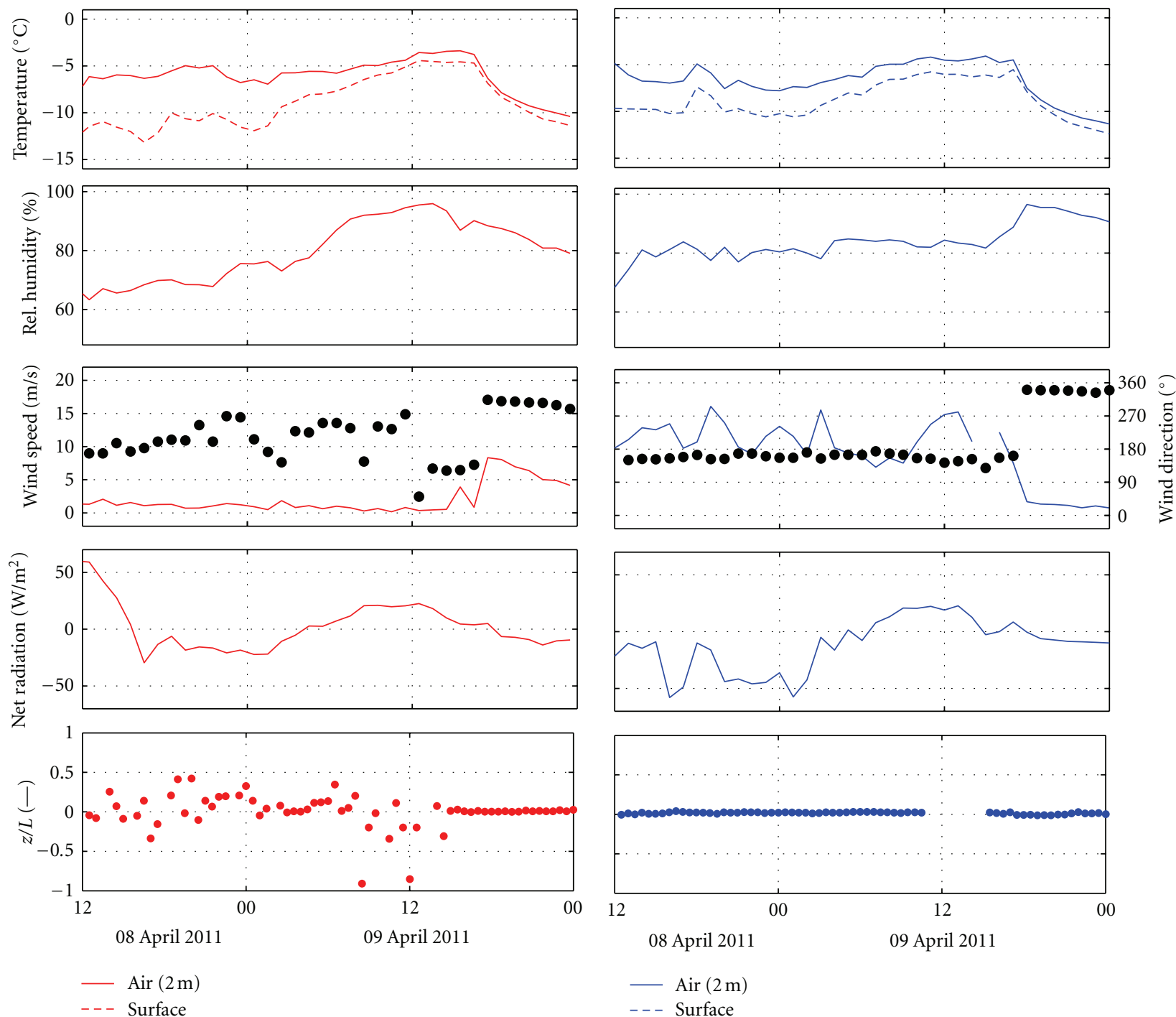

(a)

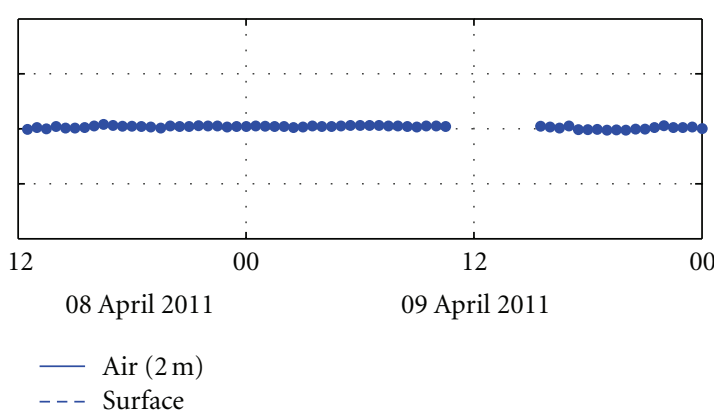

(b)

Figure 6: Temperature in $2 \mathrm{~m}$ and at the surface, relative humidity, wind direction (dots) and wind velocity (line), radiation budget and the stability parameter $z / L$ for the period 8 April and 9 April 2011 (from the top to the bottom). 


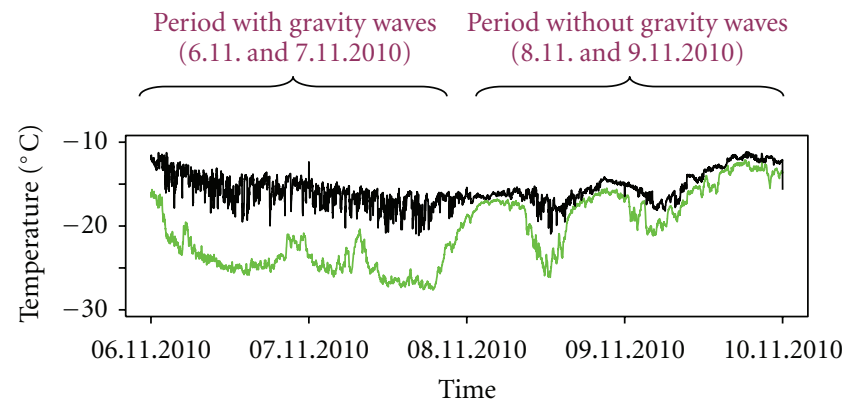

(a)

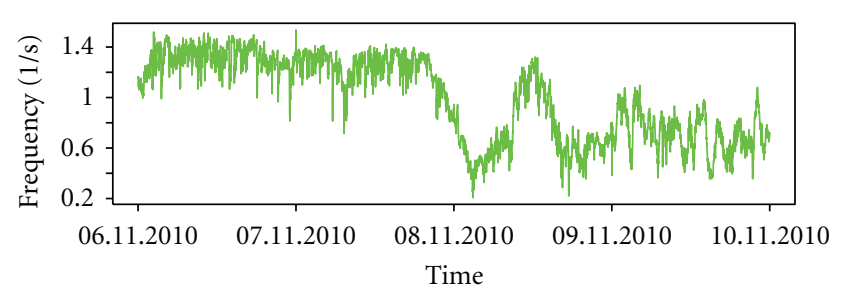

(b)

FIGURE 7: Potential temperatures ((a), green is the potential temperature at the measurement height, black at the surface) and Brunt-Vaisala frequency (in 1/s, (b)) for the period 6 November 2010, 00-10 November 2010, 24 UTC.

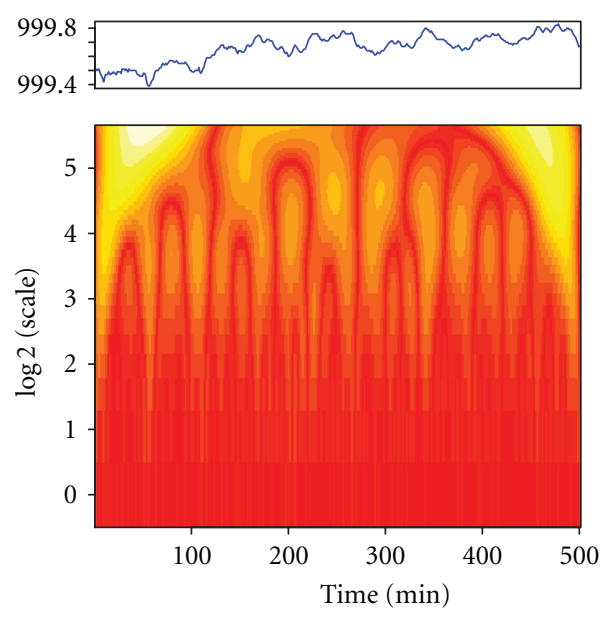

(a)
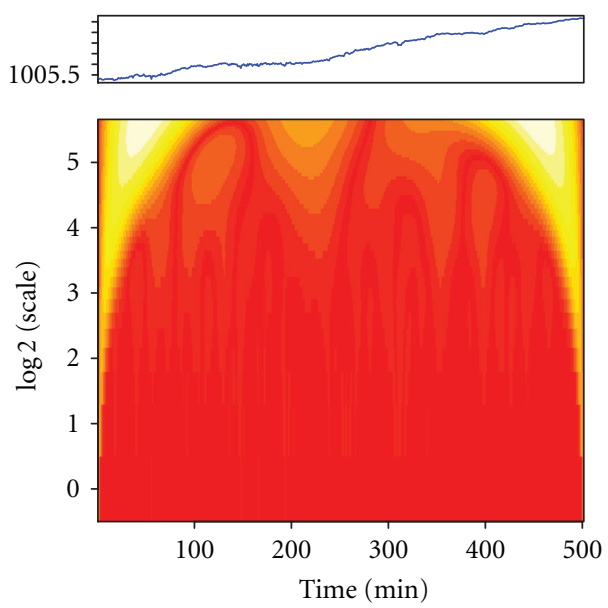

(b)

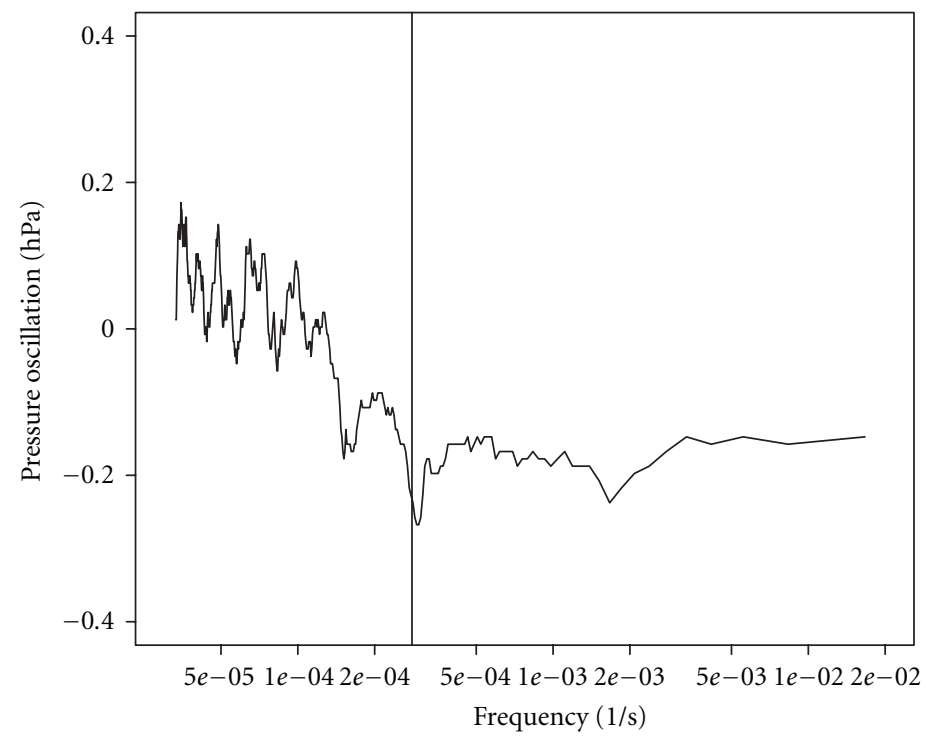

(c)

Figure 8: Wavelet coefficients of the air pressure in $2 \mathrm{~m}$ height for the period 6 November 2010, 08-16 UTC (a). Wavelet coefficients of the air pressure in $2 \mathrm{~m}$ height for the period 9 November 2010, 16-24 UTC (b). Scale means in this context delta (signal) *c (c is a continuous numbering vector with the length of the investigated signal range). The more powerful the detected signal is the more light it is in the graphic. Note: on the left side the resolution of the pressure axis is $0.1 \mathrm{hPa}$ per line, on the right side $0.5 \mathrm{hPa}$ per line (in the upper part of the graphics). The graphic at the bottom shows the frequency distribution of the investigated air pressure period with gravity waves. 
about scale range 4) are evident. In contrast, in Figure 8(b), the air pressure for a period from 9 November 2010 (16 to 24 UTC) is plotted, a period where we did not find gravity waves. Figure 8 at the bottom shows as additional information the frequency distribution of the air pressure signal from the investigated period with gravity waves, therefore, the signal mean was eliminated. The external gravity waves frequency range in this case begins at about $2.8 * 10^{-4}$ per second (marked by a line), which means nearly 1 per hour, and continues obviously in the lower frequency range. So, it is to assume that there are probably waves with different frequencies.

Our data suggest the existence of several criteria for the development of gravity waves.

First of all, clear sky conditions are needed, the outgoing longwave radiation has to be considerably larger than the incoming longwave radiation that a near surface inversion can develop. The inversion is the main precondition for the development of this kind of external gravity waves. In contrast, clouds prevent the strong radiative cooling of the atmosphere-surface-interface, there is no near-surface inversion and so the formation of near surface external gravity is suppressed. Furthermore, calm air is essential, the wind velocity has to be low $(<5 \mathrm{~m} / \mathrm{s})$, such that turbulent mixing by wind shear is suppressed. In this local case, the wind has a favoured direction (about 180-260 degrees) during the existence of gravity waves, a hint for orographical stimulated gravity waves at this site. In this direction the Broggerbreen glacier is located a few kilometers away. It is highly probable that katabatic outflow from this glacier triggers the development of the observed gravity waves, further investigations are ongoing and required.

It can be assumed that the detected gravity waves are external gravity waves without a significant vertical component, because in $10 \mathrm{~m}$ height, the gravity wave motion is almost invisible (Figure 9(a)). Internal gravity waves, which are quite well known in the stably stratified (polar) boundary layer (e.g., $[25,26])$, could develop components in all space directions.

For estimating the synoptic influence on the discussed processes and to prove the potential linkage between the large-scale flow and processes at small scales, Figure 10 shows the wind distribution in $850 \mathrm{hPa}$ pressure level for the periods 6 November 2010-7 November 2010, 12-12 UTC (a) and 8 November 2010-9 November 2010, 12-12 UTC (b), taken from the NCEP/NCAR online tool. The pressure level $850 \mathrm{~h} \mathrm{~Pa}$ was chosen, because it represents quite well the common synoptic situation, orographical effects can be probably neglected in this height for this region. Such estimates are important to improve the general knowledge about the dominant processes and more or less detailed done before for other places, like, for example, the southwest of Norway [27].

The wind is coming from northerly directions for the whole pictured space of time, a little bit more from west for the period 8 November 2010-9 November 2010, 12-12 UTC. It can be assumed that the wind distribution is not so important in this case. Fundamental in this relation is the humidity as clouds are the dominating factor in the matter of longwave radiation loss.
Another fact has to be considered in this case: during periods with gravity waves positive sensible heat fluxes are measured with the eddy covariance method (Figure 11(c)). The figure shows that exact at the times with high Brunt Vaisala frequencies and high potential temperature gradient between surface and measurement height, thus in the times when gravity waves occurs, the sensible heat flux shows positive values. It is most important to point out that these positive flux components are no turbulent fluxes, only a fictitious result of the calculation method due to the strong correlation between vertical wind and temperature in case of gravity waves [28]. The best way to get rid of the fictitious fluxes in case of gravity waves is to filter the data before flux calculation considering the Brunt Vaisala frequency to be sure to have the "pure" turbulent signal [29] for calculating the turbulent fluxes.

For detailed statements to the wavelength and phase speed of the gravity waves, different point measurements would be needed [25], which were not available for this case study.

\subsection{Spatial Variability of Sensible and Latent Heat Exchange in Arctic regions: Contemporary Turbulence Measurements at $\mathrm{Ny}$-Ålesund and the Kongsvegen Glacier}

3.2.1. A Period with Different Conditions. Figure 12 shows the sensible and latent heat fluxes for the period 8 April 2011, 12-24 UTC at the two measurement sites. On the Kongsvegen glacier strong katabatic winds at this period, coming downward the glacier from the east occurred. Probably the general synoptic situation forced the katabatic wind, Figure 13(a) shows that the wind in $850 \mathrm{hPa}$ pressure level came from south-easterly directions for the period 8 April 2011, 18-24 UTC. The shear stress caused a negative sensible heat flux and positive latent heat flux on the glacier. While on the Kongsvegen glacier the fluxes followed this typical behaviour, these values were fluctuating around zero at the eddy covariance measurement site near $\mathrm{Ny}$-Ålesund. A view on the wind direction and wind speed at the two sites makes this different behaviour understandable (Figure 12 at the bottom). In contrast to the Kongsvegen site, the wind velocity at the Ny-Ålesund site is quite low at this period; the wind direction is oscillating in the range between south and west. Apparently, the general synoptic situation plays no role for the flux behaviour near $\mathrm{Ny}$-Ålesund at this time. The mountains in the east of Ny-Ålesund may avoid this. The processes at the two measurement sites are completely different at this period; the katabatic outflow of the Kongsvegen obviously did not reach $\mathrm{Ny}$-Ålesund.

3.2.2. A period with Quite the Same Conditions. One day later, the processes on the two measurement sites changed completely. Figure 14 shows that after a short period of changeover, the fluxes at the two measurement sites showed quite the same behaviour. Looking at the wind direction and wind speed at the relevant time makes this changing behaviour (Figure 14 at the bottom) explainable. If the katabatic wind on the glacier disappeared, both sites are 


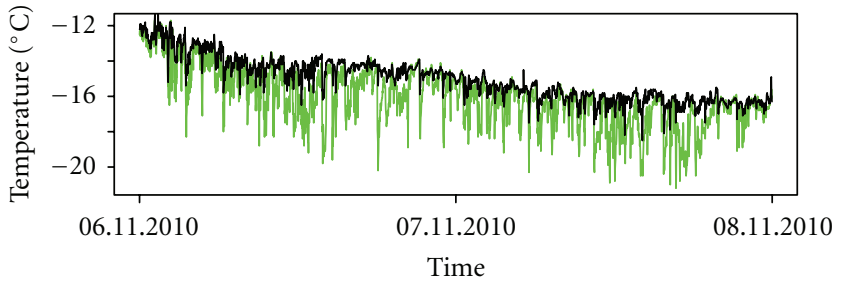

(a)

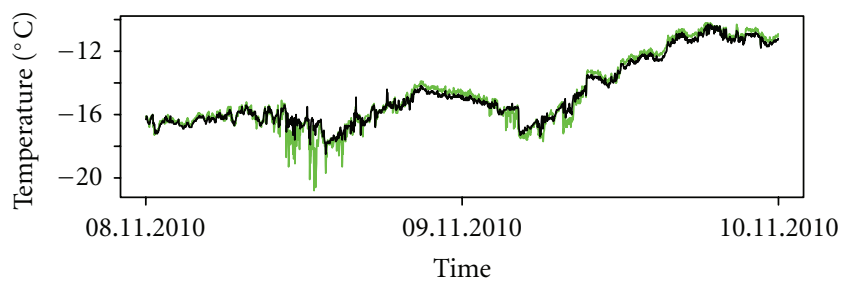

(b)

Figure 9: Temperature in 2 (green) and 10 (black) m height for 6 November-7 November 2010 (clear conditions, gravity waves can develop; (a)) and for 8 November-9 November 2010 (mostly cloudy, gravity waves are only sporadic able to develop; (b)).

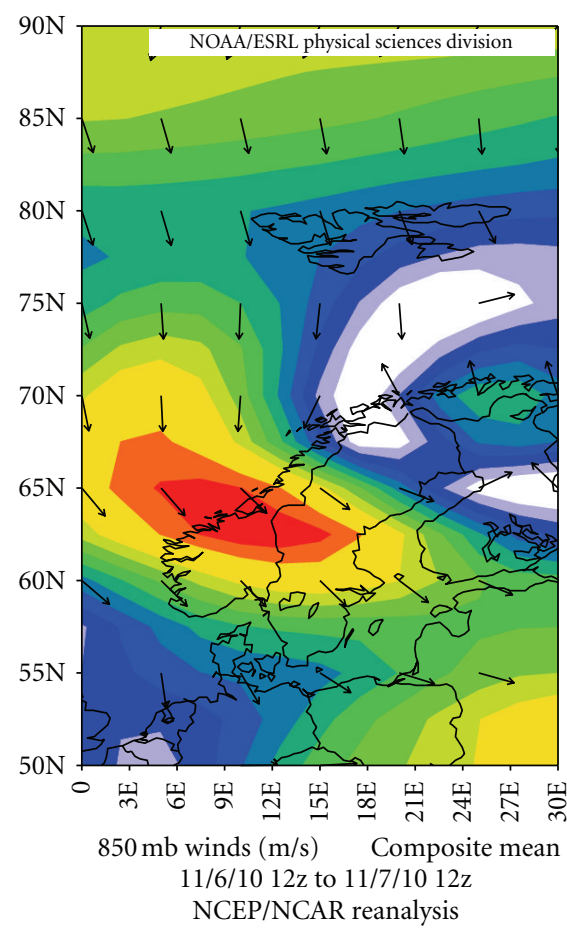

(a)

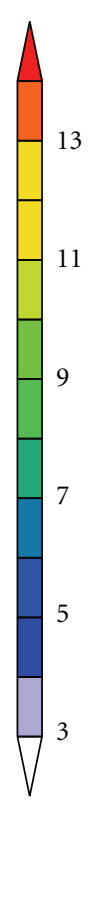

5 $50 \mathrm{~N}$

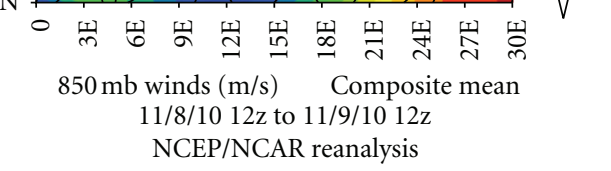

(b)

FIgURE 10: Wind distribution for the periods 6 November 2010, 12 UTC-7 November 2010, 12 UTC (a) and 8 November 2010,12 UTC-9 November 2010, 12 UTC (b), both for $850 \mathrm{hPa}$ pressure level. Source is the online tool of NCEP/NCAR.

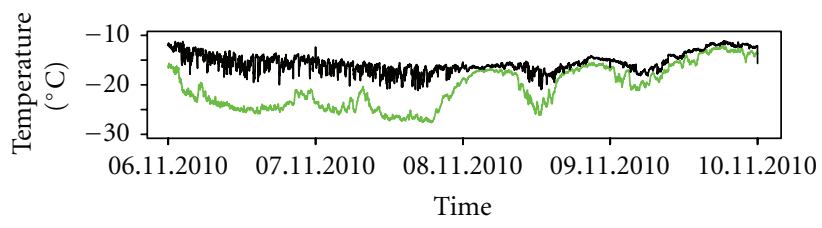

(a)

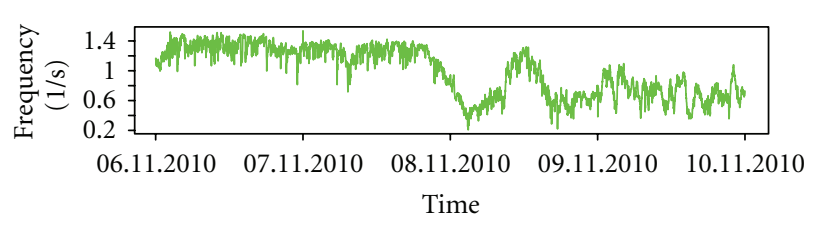

(b)

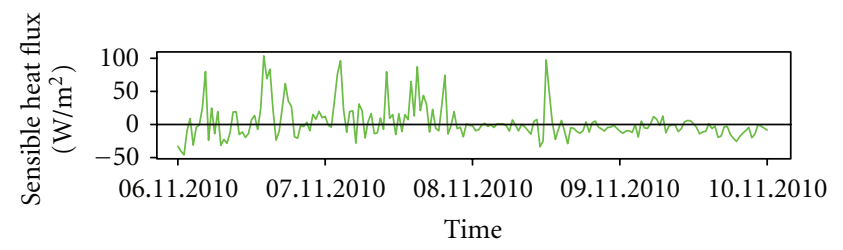

(c)

Figure 11: Potential temperatures (a), Brunt Vaisala frequencies (b), and sensible heat flux (c) for the period 6 November 2010 , 00 UTC-9 November 2010, 24 UTC. 


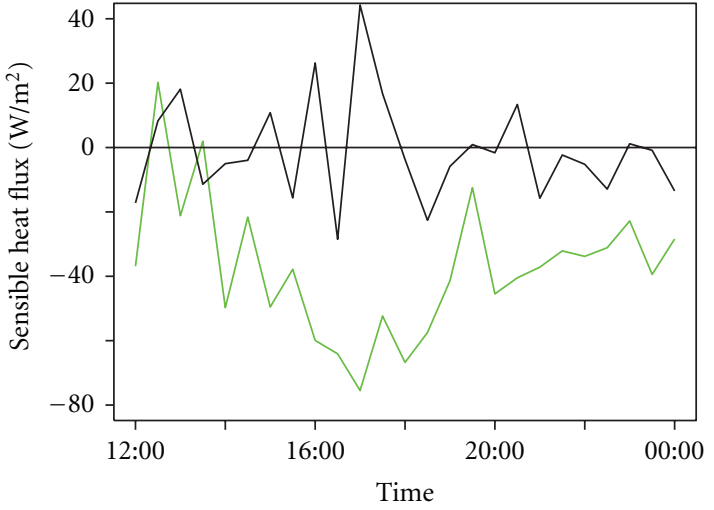

(a)

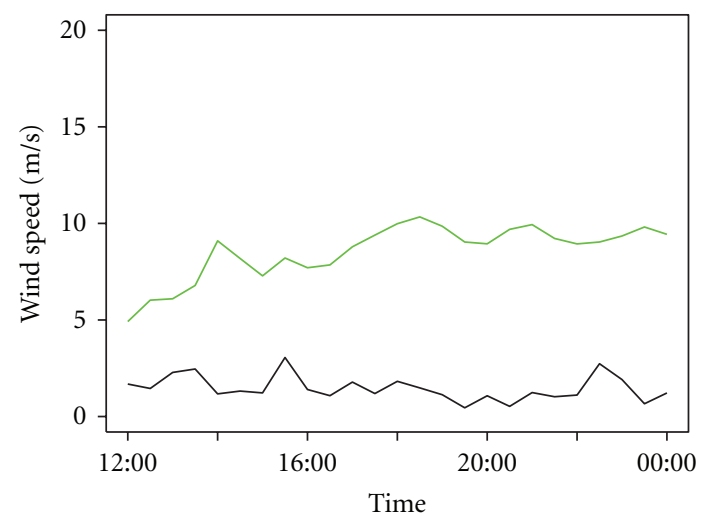

(c)

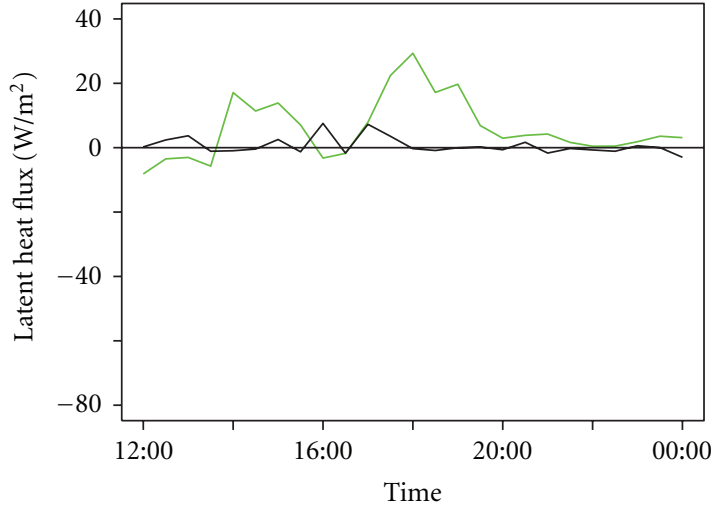

(b)

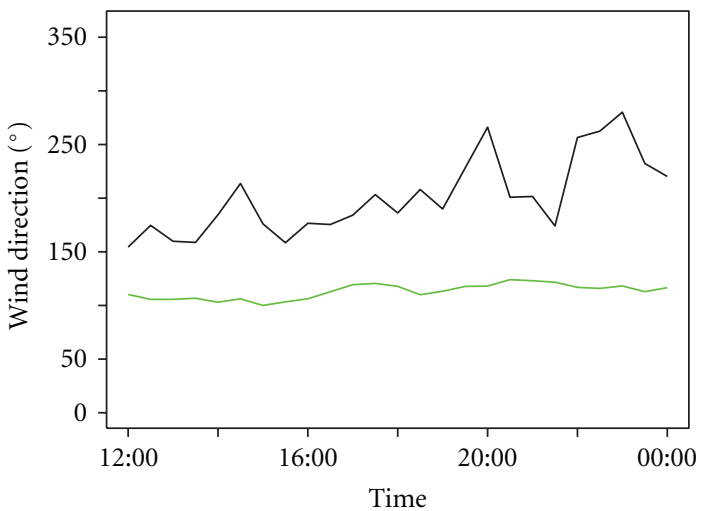

(d)

FIGURE 12: Sensible heat flux, latent heat flux, wind speed and wind direction for the period 8 April 2011 12-24 UTC. The green line are values from the Kongsvegen site, the black line from the site near Ny-Ålesund.

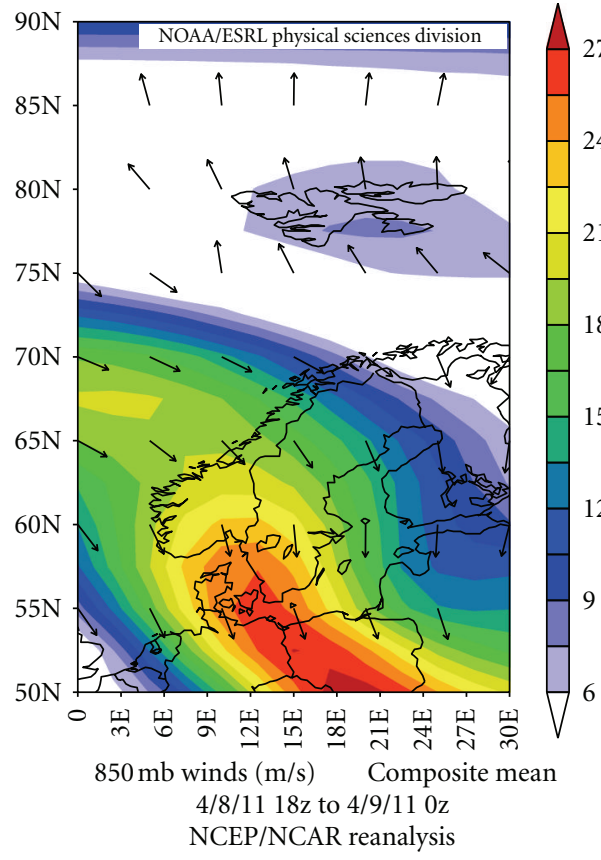

(a)

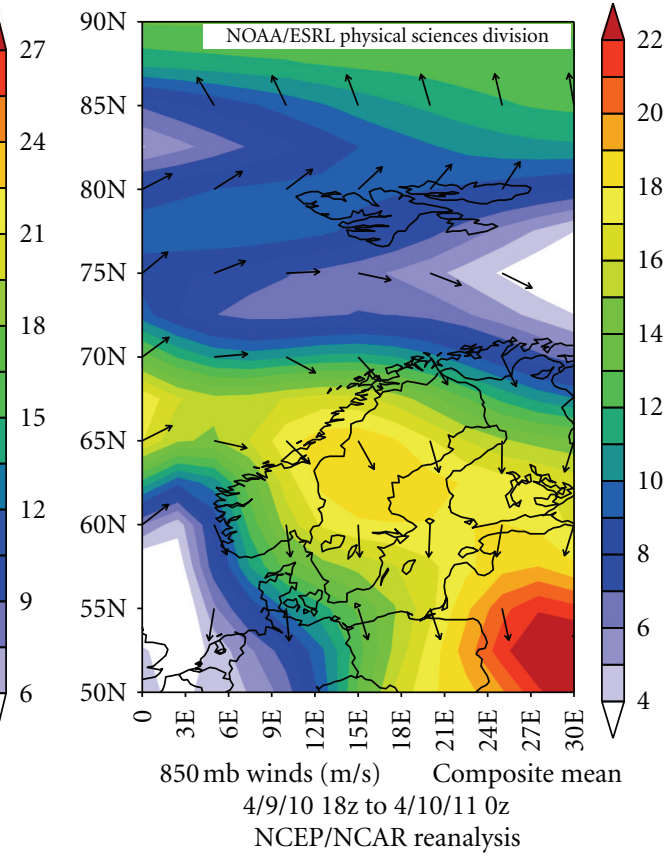

(b)

Figure 13: Wind distribution for the period 8 April 2011, 18-24 UTC in 850 hPa pressure level (a). Wind distribution for the period 9 April 2011, 18-24 UTC in $850 \mathrm{hPa}$ pressure level (b). Source for both is the online tool of NCEP/NCAR. 


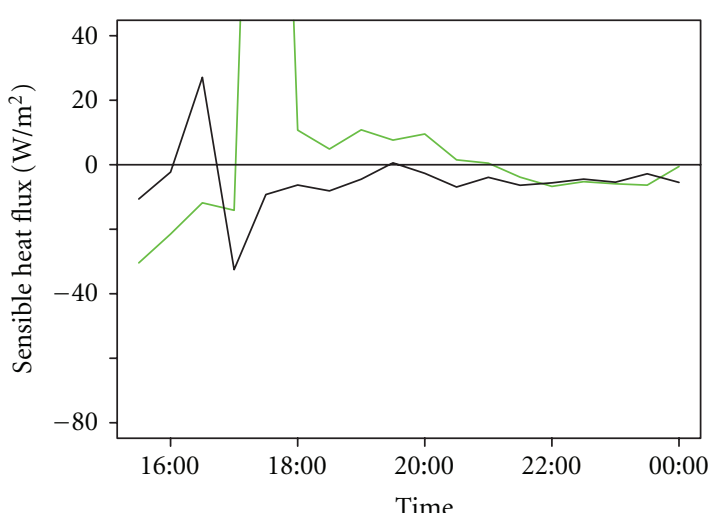

(a)

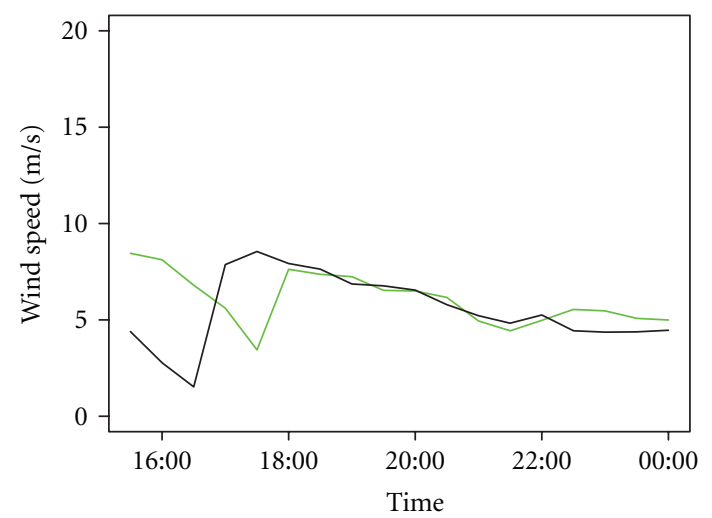

(c)

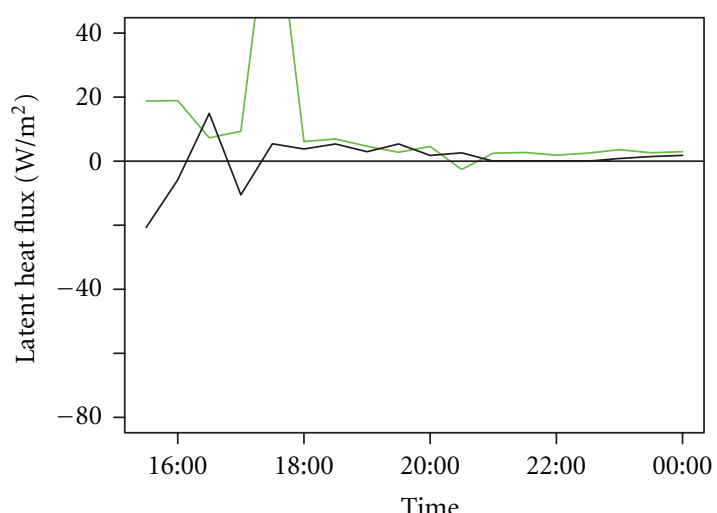

(b)

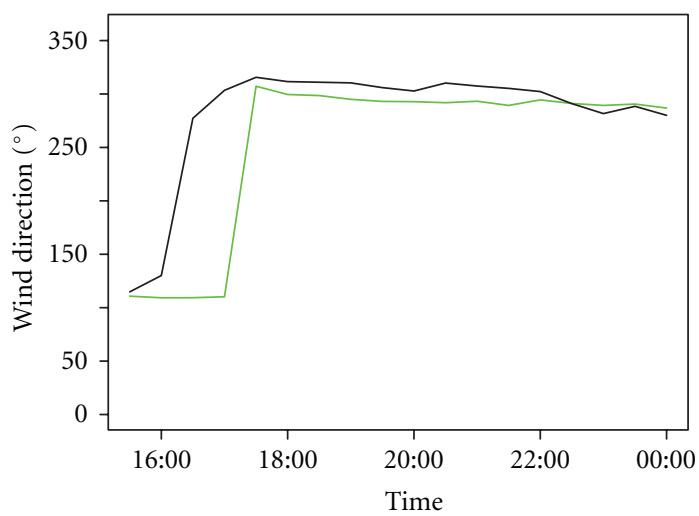

(d)

Figure 14: Sensible heat flux, latent heat flux, wind speed, and wind direction for the period 9 April 2011 15:30-24:00 UTC. The green line are values from the Kongsvegen site, the black line from the site near Ny-Ålesund.

quite comparable at this time. With the change of the wind direction on 9 April 2011 and, therefore, the change of the flux behaviour at both sites, the flux values are getting more and more equal. Figure 13(b) shows the general synoptic situation for the period 9 April 2011, 18-24 UTC in $850 \mathrm{hPa}$ pressure level. Well to see is the strong wind from westerly directions. The wind can blow upward the fjord and reaches the measurement site $\mathrm{Ny}$-Ålesund and the measurement site on the Kongsvegen glacier in the same way. So, there is a synchronization of the observed processes, the general synoptic situation seems to play an important role.

For Sections 3.2.1 and 3.2.2 differences in the surface conditions were neglected, because there was a closed snow layer at this time also near $\mathrm{Ny}$-Ålesund, for both places the same roughness $(0,24 \mathrm{~mm}$; [30]) was assumed.

\section{Conclusions}

In this work, two clear proofs for small-scale processes of boundary layer dynamics around $\mathrm{Ny}$-Ålesund, derived from two eddy covariance measurement systems, one on the Kongsvegen glacier, other on a smooth plane close to $\mathrm{Ny}-$ Ålesund, are presented.
On the one hand the formation of gravity waves during polar night conditions as example for high temporal variability of flux behaviour was detected: strong temperature inversion conditions due to longwave radiation loss and calm wind are the main preconditions for this phenomenon, which is triggered by katabatic outflow from the Broggerbreen glacier in the southwest of $\mathrm{Ny}$-Ålesund and winds from this direction flowing over the orography in this direction. To minimize the influence of temporal variability and to get the pure turbulent signal, it is recommendable for prospective work on this field to filter the raw turbulence data got by an eddy covariance system. In this way, one can get rid of the longwave components caused by gravity waves and orographical effects like secondary circulations and thereby avoid wrong conclusions while interpreting turbulence data.

On the other hand drastic differences in flux measurements on different sites at the same time were observed, among other things depending on katabatic outflows from glaciers, as example for high spatial variability of flux behaviour: the best way to deal with the spatial context in future is to provide as much measurement locations as possible and then compare.

Based on this work, we propose that Ny-Ålesund is not only influenced by katabatic outflows from Kongsvegen 
glacier, as was previously suggested [7], but additionally also from the smaller Broggerbreen and the synoptic situation. Depending on the actual main wind direction, the Kongsvegen glacier (wind from south easterly direction) or the Broggerbreen glacier (wind from south to west direction) influence the dynamics in $\mathrm{Ny}$-Ålesund, both in different ways. Therefore, in future all glaciers in Kongsfjord region and the synoptic scale blocking effect by the mountains surrounding Ny-Ålesund should be considered for understanding causes of small-scale dynamics. The small-scale variations in the near-surface behaviour of momentum, sensible and latent heat exchange measured around $\mathrm{Ny}$ Ålesund are obviously an interaction of many different local effects and the synoptic situation. Because of this issue, it is very difficult to make universal statements about the Arctic atmospheric boundary layer at this place.

So, the eddy covariance measurements will be continued on the described measurement site near $\mathrm{Ny}$-Ålesund. A radiometer (for measurements of temperature and humidity profiles) and a wind Lidar (for measurements of 3D wind profiles) will support the eddy covariance measurements to achieve a complete as possible view on the conditions of the atmospheric boundary layer and to observe the entrainment behaviour between the atmospheric boundary layer and the free troposphere.

To get more knowledge about the near surface temperature and humidity profiles, additional sensors to determine these quantities were installed in 4,7 , and $10 \mathrm{~m}$ height on the already established BSRN weather mast, which is not far away from the eddy covariance system. Finally, for 2012, the additional usage of a tethered balloon system is planned.

\section{Acknowledgments}

Special thanks go to the crew of the AWIPEV station, namely Christian Konrad, for checking the AWI eddy system in $\mathrm{Ny}$ Allesund. The PAMARCMiP campaign was mainly organized by Andreas Herber (AWI, Bremerhaven) and Walter Strapp (Environment Canada, Toronto). This research was also supported by the Austrian Science Fund (FWF, grant I 369-B17). Field work was performed in cooperation with Norwegian Polar Institute, Tromsoe (Jack Kohler and Mats Björkmann) and was effectively assisted by Walter Steinkogler and Florian Bilgeri (Innsbruck University). The turbulence instruments at Kongsvegen glacier were provided by the Geophysical Institute, University of Bergen, where Tor de Lange is particularly thanked for providing his technical expertise. AWI Potsdam (Marion Maturilli) is thanked for providing $\mathrm{Ny}$-Ålesund meteorological data. The project is registred under the RIS-ID 4763, the AWI turbulence measurements under RIS-ID 4331.

\section{References}

[1] M. Tjernström, M. Žagar, G. Svensson et al., "Modelling the Arctic boundary layer: an evaluation of six ARCMIP regionalscale models using data from the SHEBA project," BoundaryLayer Meteorology, vol. 117, no. 2, pp. 337-381, 2005.
[2] J. Lüers and J. Bareiss, "Direct near-surface measurements of sensible heat fluxes in the Arctic tundra applying eddy covariance and laser scintillometry-the Arctic Turbulence Experiment 2006 on Svalbard (ARCTEX-2006)," Theoretical and Applied Climatology, vol. 105, no. 3-4, pp. 387-402, 2011.

[3] S. Westermann, J. Lüers, M. Langer, K. Piel, and J. Boike, “The annual surface energy budget of a high-arctic permafrost site on Svalbard, Norway," Cryosphere, vol. 3, no. 2, pp. 245-263, 2009.

[4] S. Basu, F. Porté-agel, E. Foufoula-Georgiou, J. F. Vinuesa, and M. Pahlow, "Revisiting the local scaling hypothesis in stably stratified atmospheric boundary-layer turbulence: an integration of field and laboratory measurements with largeeddy simulations," Boundary-Layer Meteorology, vol. 119, no. 3, pp. 473-500, 2006.

[5] S. Westermann, Sensitivity of permafrost [M.S. dissertation], University of Heidelberg, 2010.

[6] K. Papadopoulos, The summer climate of kongsvegen glacier [M.S. thesis], Institute for Marine and Atmospheric Research Utrecht, Utrecht University, 2010.

[7] H. J. Beine, S. Argentini, A. Maurizi, G. Mastrantonio, and A. Viola, "The local wind field at Ny-Ålesund and the Zeppelin mountain at svalbard," Meteorology and Atmospheric Physics, vol. 78, no. 1-2, pp. 107-113, 2001.

[8] S. Argentini, A. P. Viola, G. Mastrantonio, A. Maurizi, T. Georgiadis, and M. Nardino, "Characteristics of the boundary layer at Ny-Ålesund in the Arctic during the ARTIST field experiment," Annali di Geofisica, vol. 46, no. 2, pp. 185-196, 2003.

[9] T. Vihma, T. Kilpeläinen, M. Manninen et al., "Characteristics of temperature and humidity inversions and low-level jets over Svalbard fjords in spring," Advances in Meteorology, vol. 2011, Article ID 486807, 14 pages, 2011.

[10] V. Vitale and R. Udisti, "Climate Change Tower Integrated Project (CCT-IP) A scientific platform to investigate processes at the surface and in the low troposphere," Geophysical Research Abstracts, vol. 12, EGU2010-10876-1, 2010.

[11] M. Mauder and T. Foken, Documentation and Instruction Manual of the Eddy Covariance Software Package TK3, vol. 46 of Arbeitsergebnisse Universität Bayreuth, Abteilung Mikrometeorologie, 2011.

[12] M. Mauder, T. Foken, R. Clement et al., "Quality control of CarboEurope flux data-part 2: inter-comparison of eddycovariance software," Biogeosciences, vol. 5, no. 2, pp. 451-462, 2008.

[13] T. Foken, M. Aubinet, and R. Leuning, "The eddy-covariance method," in Eddy Covariance: A Practical Guide to Measurement and Data Analysis, M. Aubinet, T. Vesala, and D. Papale, Eds., pp. 1-19, Springer, Dordrecht, Heidelberg, 2012.

[14] T. Foken, M. Göckede, M. Mauder, L. Mahrt, B. D. Amiro, and W. J. Munger, "Post-field data quality control," in Handbook of Micrometeorology: A Guide for Surface Flux Measurements and Analysis, X. Lee, W. J. Massmann, and B. Law, Eds., pp. 181208, Kluwer, Dordrecht, The Netherlands, 2004.

[15] T. Foken, R. Leuning, S. P. Oncley, M. Mauder, and M. Aubinet, "Corrections and data quality," in Eddy Covariance: A Practical Guide to Measurement and Data Analysis, M. Aubinet, T. Vesala, and D. Papale, Eds., pp. 85-131, Springer, Dordrecht, The Netherlands, 2012.

[16] P. Skeie and S. Gronas, "Strongly stratified easterly flows across Spitsbergen,” Tellus A, vol. 52, no. 5, pp. 473-486, 2000. 
[17] A. D. Sandvik and B. R. Furevik, "Case study of a coastal jet at Spitsbergen - comparison of SAR- and model-estimated wind," Monthly Weather Review, vol. 130, no. 4, pp. 1040 1051, 2002.

[18] H. Svendsen, A. Beszczynska-Møller, J. O. Hagen et al., "The physical environment of Kongsfjorden-Krossfjorden, and Arctic fjord system in Svalbard," Polar Research, vol. 21, no. 1, pp. 133-166, 2002.

[19] S. Argentini, A. Viola, G. Mastrantonio, G. Maurizi, T. Giorgiadis, and M. Nardino, "Dynamics of the atmospheric boundary layer at Ny-Ålesund," in Proceedings of the 8th Workshop Italian Research on Antarctic Atmosphere. Societa Italiana di Fisica Conference, G. Giovanelli and M. Colacino, Eds., vol. 69, pp. 175-185, Italian Physical Society, 2000.

[20] J. Hartmann, F. Albers, S. Argentini et al., "Arctic Radiation and Turbulence Interaction Study (ARTIST)," Report on Polar Research 305, Alfred-Wegener-Institute for Polar-und Meeresforschung, Bremerhaven, Germany, 1999.

[21] H. Sodemann and T. Foken, "Special characteristics of the temperature structure near the surface," Theoretical and Applied Climatology, vol. 80, no. 2-4, pp. 81-89, 2005.

[22] J. Lüers and J. Bareiss, "The effect of misleading surface temperature estimations on the sensible heat fluxes at a high Arctic site-the Arctic turbulence experiment 2006 on Svalbard (ARCTEX-2006)," Atmospheric Chemistry and Physics, vol. 10, no. 1, pp. 157-168, 2010.

[23] S. Zilitinkevich and P. Calanca, "An extended similarity theory for the stably stratified atmospheric surface layer," Quarterly Journal of the Royal Meteorological Society, vol. 126, no. 566, pp. 1913-1923, 2000.

[24] R. B. Stull, An Introduction to Boundary Layer Meteorology, Kluwer Academic, Dodrecht, The Netherlands, 1988.

[25] J. Egger, C. Wamser, and C. Kottmeier, "Internal atmospheric gravity waves near the coast of Antarctica," Boundary-Layer Meteorology, vol. 66, no. 1-2, pp. 1-17, 1993.

[26] S. S. Zilitinkevich, "Third-order transport due to internal waves and non-local turbulence in the stably stratified surface layer," Quarterly Journal of the Royal Meteorological Society, vol. 128, no. 581, pp. 913-925, 2002.

[27] M. O. Jonassen, H. Olafsson, J. Reuder, and A. J. Olseth, "Multi-scale variability of winds in the complex topography of southwestern, Norway," Tellus A, vol. 64, Article ID 11962, 2012.

[28] T. Foken and B. Wichura, "Tools for quality assessment of surface-based flux measurements," Agricultural and Forest Meteorology, vol. 78, no. 1-2, pp. 83-105, 1996.

[29] G. Heinz, D. Handorf, and D. Foken, "Strukturanalyse der atmosphärischen Turbulenz mittels Wavelet-Verfahren zur Bestimmung von Austauschprozessen über dem antarktischen Schelfeis, Arbeitsergebnisse Universität Bayreuth, Abteilung Mikrometeorologie," 1999.

[30] C. Gromke, C. Manes, B. Walter, M. Lehning, and M. Guala, "Aerodynamic roughness length of fresh snow," BoundaryLayer Meteorology, vol. 141, no. 1, pp. 21-34, 2011. 

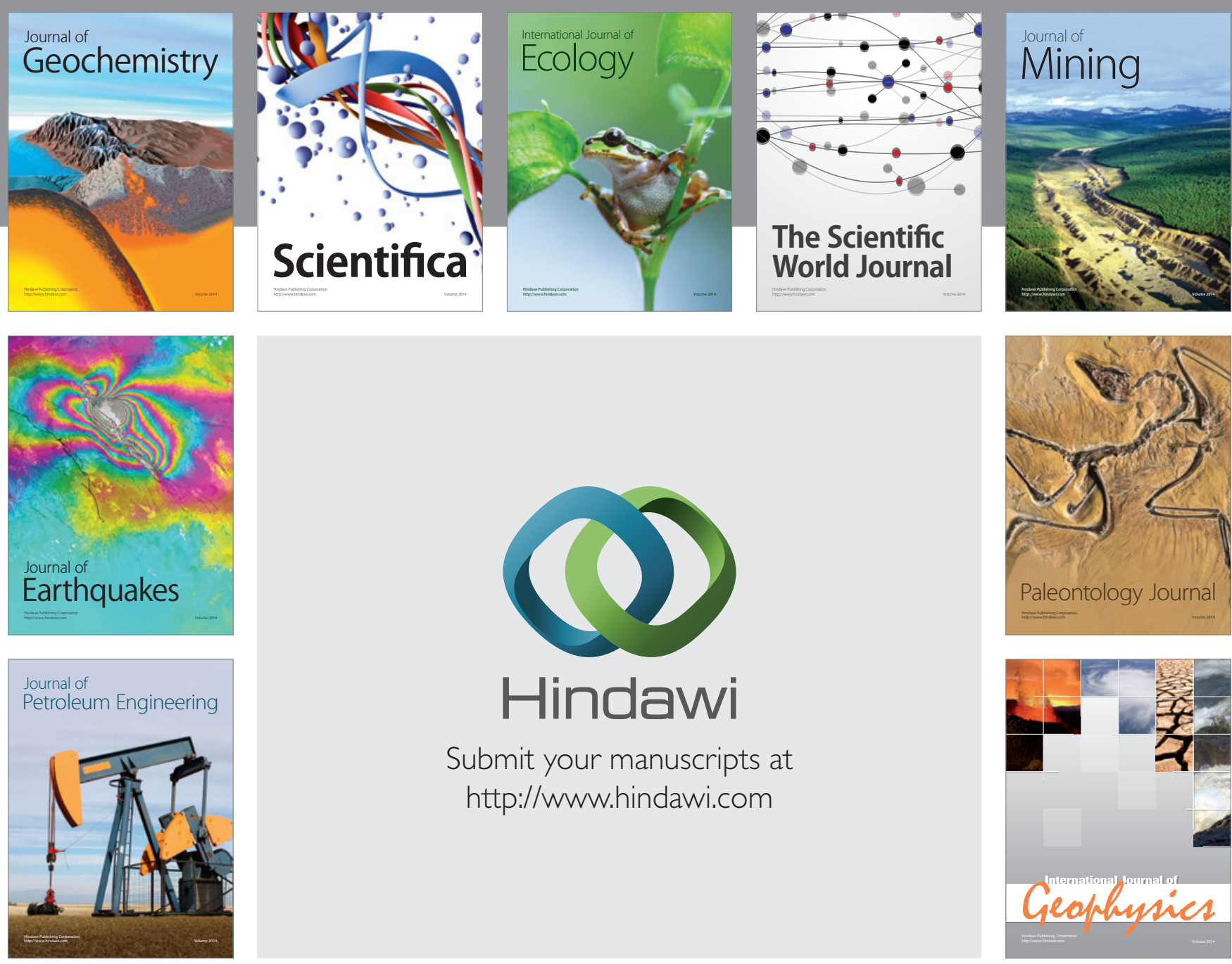

Submit your manuscripts at

http://www.hindawi.com
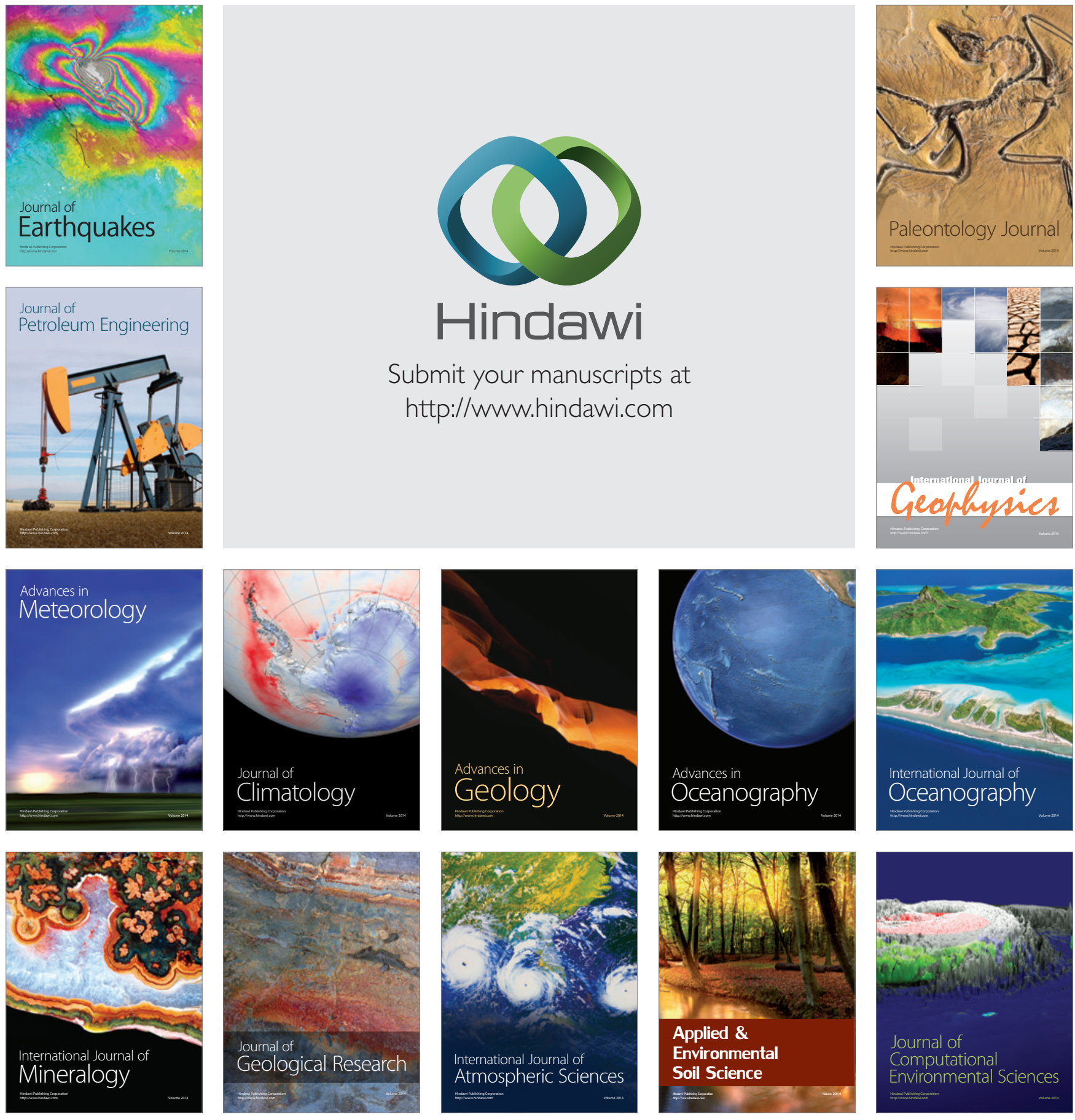